\title{
OIL AND GHANA'S 2012 PRESIDENTIAL ELECTIONS Reinvigorating the 'Resource Curse'?
}

\section{Charles Nyuykonge and Keitumetse Letsoalo}

\begin{abstract}
Charles Nyuykonge is an independent consultant, political analyst and peace and security practitioner specialising in teaching, training, research, policy analysis and programme design. While completing his $\mathrm{PhD}$ (International Relations) at the University of the Witwatersrand he is a Human Rights Observer for the African Union Support Mission for Mali and the Sahel with research interests in African Affairs, Governance, Geopolitics; Human Rights and Peace and Security. e-mail: nyuykonge@gmail.com
\end{abstract}

Keitumetse Letsoalo is completing her master's degree in Political Studies at the University of the Witwatersrand. e-mail: keitumetseletsoalo9@gmail.com

\begin{abstract}
The threat posed to burgeoning democratic dispensations by natural resources could not be more glaring than it is in Ghana following the discovery of large quantities of oil in what has been named the Jubilee Field. While it is evident that oil revenues could bring about economic transformation and benefits for the citizens of Ghana, prudent economic management of the resources is required. At the same time, the oil boom may prove to be a challenge to Ghana's democratic development if it brings, as it has elsewhere in Africa, an increase in corruption, authoritarianism and conflict. The Jubilee Field raised the stakes in the 2012 presidential election. In their manifestos the National Democratic Congress and the New Patriotic Party, the two leading political parties in Ghana, each made a different proposal about what should be done with the oil revenue. Against this backdrop we posit that the relevance of the 'resource curse' dictum cannot be dismissed. For political parties the stakes remain high. The heightened attention paid to oil adds currency to the conception that resources have a long-standing destabilising effect on African democracies. This article argues that unless visible and apolitical accountable structures are created to manage the oil, multinational lobbyists could fuel post-election political tensions in subsequent elections by funding the pursuit of power of the parties, thus accelerating an end to Ghana's long-celebrated democratic stability.
\end{abstract}




\section{INTRODUCTION}

Resources have been well documented as a source of dispute in some of Africa's intractable conflicts, such as that in the Democratic Republic of Congo (DRC), Darfur and Somalia and their discovery in any country should be carefully celebrated. This caution is particularly appropriate in the Ghanaian context, where the recent discovery of oil has elicited high hopes and expectations for socioeconomic renewal and political development.

Since the inauguration of the Fourth Republic, in 1992, Ghana's politics has been dominated by two main political parties, namely, the National Democratic Congress (NDC) and the New Patriotic Party (NPP) (Throup 2011, p 4), each of which has enjoyed almost equal levels of support among voters, exemplified by frequent alternation of power between the two parties, as well as acceptance of electoral outcomes without undue recourse to violence.

In the December 2008 election, for example, the failure of the NPP's candidate Nana Akufo-Addo to secure the statutory $50 \%+1$ of the total vote cast in the presidential elections in the first ballot caused the NPP barons to decry the outcome. However, then President John Kufuor convinced his supporters to accept a second round. When the NDC candidate, John Atta-Mills, won the run-off election by $0.46 \%$ President Kufuor called for the result to be accepted, making it clear that Ghanaians accepted constitutional democracy as expressed through the ballot box. It also seems that President Kufuor's statesmanship was critical in holding the NPP and Ghana's despondent population together.

However, following the 2012 elections, the lack of a leader of the likes of Kufuor, an infrastructure that fails to meet the country's needs and, more crucially, the discovery of oil, heightened the stakes and triggered an immediate objection, by the NPP and a dispute that challenged Ghana's reputation as a politically mature state (Maplecroft 2012, p 1).

Beyond these election battles Ghana's fast track resolution mechanism for dealing with election related disputes has been saluted by both national and international observers as being free and fair (Commonwealth Observer Group 2012, p 14). The decision of the Electoral Commission of Ghana (ECG), an independent body consisting of seven members, can be challenged through the Supreme Court within 21 days of the declaration of the results.

The NPP's decision to challenge the election result - something that had not been done in several previous elections - hints at the party's strong desire to control Ghana's newly discovered oil wealth. Given the fact that there were residual tensions from the 2008 elections (Omotola 2012) and the fact that the winner of the 2012 elections would manage the oil revenue, the objection raised fears that violence could ensue from the heightened stakes introduced by the discovery of oil. 
This article investigates the effects Ghana's oil could have on future elections. It posits that drawing on the lessons of the 2012 elections, especially the premium placed on oil revenues by both the NDC and NPP in their election campaigns, adequate steps must be taken to avoid falling into the pitfalls of the 'resource curse', which can engender underdevelopment and conflict. The 2012 election should be seen as a warning to Ghana's leaders to ensure that oil management does not become a political football.

Although Ghana does not have the significant amount of oil reserves of its neighbour, Nigeria, whose Niger Delta region has been the focal point of intractable instability (LaMonica \& Omotola 2013), the production of oil does present various opportunities: if it is well managed, the revenue accrued from oil production could help the country become a middle-income state. It could also provide employment opportunities and foster local participation and development (Throup 2011, p 9). The Jubilee Oil Field has reserves of approximately two billion barrels of oil and 5 000-billion cubic feet of gas. It is believed that production will continue until 2030 (Prempeh \& Kroon 2012, p 3) and will account for \$1-billion and \$1.5-billion annually, which will amount to six to nine percent of Ghana's gross domestic product (Prempeh \& Kroon 2012, p 3).

If care is not taken the potential role of multinational corporations in supporting dissenting political factions as a lobbying strategy to control oil markets could run Ghana aground, as has competition over resources in the DRC and Sudan. This could weaken government institutions and reduce Ghana's economic performance (Kapela 2009, p 11). Thus, rather than the discovery of oil contributing to the growth of Ghana's GDP as projected, it might have repercussions that would lend credibility to the 'paradox of plenty', also known as the resource curse - the thesis that suggests that states with resource wealth tend to perform more poorly economically than those without.

This article also argues that it is time to reconsider the 'winner-takes-all' nature of Ghana's electoral system (Prempeh \& Kroon 2012, p 3), which is a political culture built on a cabalistic system of government where the party that wins control of Parliament or the presidency manages political and material resources, often in favour of influential interest groups and public investments that have short-term pay-offs. The need, therefore, for a political reconfiguration in which visibly apolitical and accountable structures are created to manage Ghana's resources could not be more pressing. Failure to do this could have dire consequences for Ghana's nascent democracy.

The paper has four thematic sections. The first provides some theoretical information about the relationship between oil and democracy. The cases of Nigeria and Sudan portray oil as a trigger of both intra- and interstate conflict, with dire humanitarian consequences for civilians. 
The second section reflects on how Ghana's discovery of oil has steadily changed (and will continue to influence) the contours of democratisation. This section describes briefly how oil discovery energised the political elite while weakening the democratisation process before the 2012 election.

This section is followed by a reflection on the role of oil in the 2012 presidential election. The article argues that oil became a major issue in the election campaigns and divergent party proposals on how oil should or would be managed during each party's tenure became one of the most crucial factors in the voters' choice of candidate.

In the concluding section the paper recommends strategies for avoiding the resource curse. Among these are: strengthening transparency and accountability and reinvesting oil revenues in productive ventures such as job creation, infrastructural development, poverty eradication and research grants for academically deserving and financially needy Ghanaians.

\section{RELATIONSHIP BETWEEN OIL AND DEMOCRATISATION}

Policy research into oil and democracy has reached a fairly universally accepted conclusion that oil discovery in Africa has, more often than not, given birth to crises. According to Luke Patey (2007, p 5), '[t]he tragedy of civil war, corruption, and poverty of many African oil producers represents one of the most baffling paradoxes on the continent.' Although states such as Ghana possess a potential basis for rapid development pursuant to the discovery of oil, a great deal depends on 'getting the politics right' (Obi 2007, p 9). For this reason successful oil administration can strengthen the democratisation and governance process. Cyril Obi, a renowned expert in oil and environmental politics, laments, however, that '[c]onflict [ensuing from oil] occurs only as a result of the politicization of the oil factor, in ways that make the exclusive control of oil and its distribution, the [affair of a few]' (Obi 2007, p 5).

Leading studies in the field (Cook 1970; Beblawi 1987; Beblawi \& Luciani 1987; Chaudhry 1997; Yates 1996; Karl 1997; Rose 1999, 2001) have established what may generally be regarded as the conventional wisdom about the relationship between oil and democracy, showing how oil, unconditionally, hinders democracy or promotes authoritarianism.

The argument goes that oil rents breed rentier states, that is, states that depend largely on external rents / revenue, where the rent accrues directly to the government and only a few are engaged in the acquisition of the rent (wealth). As the argument goes, the majority does not get involved in the sharing of the wealth (Rose 2001, p 329). These tendencies not only promote corruption and violence, they also undermine development. It has also been argued that such 
crude democracies are easily susceptible to oil shocks resulting from disruption in production or a general fall in the price of oil, with a telling impact on the level of political freedom and democracy (Ramsay 2007). Others have argued that the volume of oil plays a prominent role in determining its effects on democracy, positing that the more oil, the less democracy (Tsui 2005).

All these studies, though conducted using different methods and models, point in one direction - the resource curse, which describes a situation where abundant mineral resources and increasing resource revenues undermine democracy and development.

From the studies the sins of oil, like those of most mineral resources, have been identified as the rentier effect, the repression effect and the modernisation effect (Rose 2001). While the rentier effect posits that resource-rich governments use low tax rates and patronage to relieve pressures for greater accountability, the repression effect argues that resource wealth retards democratisation by enabling governments to boost their funding for internal security. The modernisation effect holds that growth based on the export of oil minerals fails to bring about the social and cultural changes that tend to produce democratic government (Rose 2001; Dunning 2008).

In Nigeria and Sudan there is a close connection between oil, the state and democratic processes. Oil, for instance, contributes about $40 \%$ of Nigeria's GDP, $70 \%$ of federal government revenue and $92 \%$ of its foreign exchange earnings (Obi 2007). Similarly, about 70\% of Sudan's total export revenue comes from oil exports. Whereas in 2006 and 2007 increases in oil production, high oil prices, and large inflows of foreign direct investment amplified Sudan's economy and steadied its GDP growth to over 10\%, the country plunged into civil war barely a year later. The war was triggered by disputes over the way the oil should be managed and who or which regions should be its beneficiaries.

Although the civil war was disguised as a religious conflict between the Muslim North and a largely Christian South, analysts believe this dynamic was peripheral and that the real reason was the control of Sudan's rich oil reserves and the wealth they bring. The conflict became extremely brutal, with untold loss of life, large numbers of internally displaced persons and refugees, many undocumented cases of rape and the wanton destruction of state and private property.

Empirical researchers, for example, Ross (2001), have found clear links between poor governance, poverty and the exploitation of oil, gas and minerals. To Ross oil dependence is a recipe for high rates of child malnutrition, low healthcare spending, low school enrolment rates and poor adult literacy - all of which are governance matters.

According to Ross there are two schools of thoughts about the relationship between oil and governance, one suggesting that oil enhances governance and 
supports the attainment of economic growth and stability, the other arguing that some states were better off without oil. Rose, however, subscribes to the first school of thought but believes that '[many countries - like Angola, Nigeria and Sudan] would clearly be better off if they had had no oil in the first place' (Rose 2001).

Ghana is likely to learn a lesson or two from two of African leading oil giants. It is also noteworthy that, apart from having good diplomatic relations, Nigeria and Ghana share some striking similarities. These include their multiethnic composition, the challenge of regional cleavages connected to the legacy of colonial administrative policies, prolonged periods of military rule and elitedominated politics.

Historically, Nigeria began exporting oil in 1958 and Sudan in 1999. Nigeria also went through a gruelling three-year civil war, from June 1967 to January 1970, while the Sudan was embroiled in an intractable conflict from 2008. In both cases oil played a critical role in disrupting governance.

In post-war Nigeria the 1970s oil boom substantially expanded the state's economy, as was the case in Sudan between 2006 and 2007. Oil management became the focal point of governance and, by the 1980s, the discourse had shifted to 'control, mismanagement, and ownership of oil by the national [elite] versus accountable leadership', with a view to guaranteeing the long-term interests of citizens. This discourse has dominated public opinion and the instability of the Niger Delta has been largely attributed to under-development of the region (LaMonica \& Omotola 2013). In light of this, its discovery in Ghana foreshadows some potential instability among communities living around the Jubilee Oil Field, with broader ramifications for the state and the country's governance.

\section{THE DISCOVERY OF OIL AND THE CHANGING CONTOURS OF DEMOCRATISATION}

Now that oil has come to the forefront of the political economy, it remains to be seen how the struggle for oil revenue among competing groups/party traditions will begin to shape and reshape the democratization process in Ghana. If not well managed, the discovery of oil may alter the equilibrium and stability of democratization in Ghana.

Omotola 2012, p 163

The chances of this prediction coming true appear increasingly feasible given the realities of the 2012 elections. As the presidential election revealed, both the NDC and the NPP aspire to attain resource-led growth. During the elections petroleum 
politics became a recurrent salient issue of contention between the two parties, each accusing the other of corrupt dealings associated with oil.

Kosmos Energy's stake in the Jubilee Oil Field became an issue of contention after the NDC government, which took office in 2009, alleged that perhaps President Kufuor and his associates had profited from oil production contracts with the company.

Collier \& Venables $(2009$, p 2) have warned about governments that appear to be concerned with the short term. Any tendencies whereby governments make decisions that are likely to lead to excessive spending or opportunistic behaviour with regard to resource companies will not have a positive impact in the long run.

When it came to power in 2009 the NDC inquired about the contract negotiations between the previous government and Kosmos Energy and, when Kosmos tried to sell its stake in the Jubilee field to Exxon Mobile, the issue generated considerable publicity, which led to Exxon Mobile relinquishing its attempt to purchase (Throup 2011, p 9).

The promise of oil revenue distribution is likely to be a significant factor in voting patterns within Ghana for many years to come. Prempeh \& Kroon (2012, p 5) have noted that there are visible shortcomings in public financial management. There have been discrepancies between the budget and actual spending. Thus fiscal discipline and macroeconomic management suffered during the elections as political parties spent heavily on campaigning. Another issue that has emerged is that Ghana lacks a long-term national development plan as every new party administration has followed its own short- to medium-term national development plan and expenditure priorities based upon its own manifestos (Prempeh \& Kroon 2012).

The promise of oil revenue has raised the expectations of many Ghanaians, including political parties. In the lead-up to the 2012 elections both parties expressed their intention to use oil revenue to deal with Ghana's development needs. Many had speculated that the 2012 elections would result in partisan conflict, as the winner would preside over oil revenues accrued from the Jubilee field and the winning party would be able to secure its place in office for several terms (Prempeh \& Kroon 2012, p 21) if corrupted by the oil wealth. Wantchekon (2000, p 836) has also stated that governments with abundant mineral resources have more discretion about spending the proceeds and also have an informational advantage over the opposition as to the amounts involved.

Wantchekon (2000, p 819) asserts that in states where high levels of income from resources are available politics is dominated not by ideology but by issues associated with resource rents and voters will select political parties on the basis of credible promises to deliver resource rents. Wantchekon (2009, p 821) also argues that when the capacity of the state is weak and the state cannot enforce laws, 
incumbent political parties have a large amount of discretion about how resource rents are distributed. Therefore, if the opposition cannot break the advantage of the incumbent government it means resource rents will translate into one-party dominance, as has been the case in Botswana (Wantchekon 2000, p 821).

In such cases some opposition parties may resort to unconstitutional means of challenging the incumbent's advantage, which may lead to instability. Incumbent politicians may ban the opposition party, co-opt it into the ruling party or use the resource rents to buy off the opposition (Wantchekon 2009, p 821). Thus Wantchekon (2000, p 822) cautions that even within democratic systems where there is political competition dependency on resources may translate into authoritarian government and this, in turn, may make it difficult to consolidate democracy.

Throup (2011, p 8) alludes to the fact that the combination of Ghana's patronage politics and its weak institutions may exacerbate corruption. The zerosum game increases the risk of violence surrounding elections and also raises the possibility that the losing party may not accept the results. Cabrales \& Hauk (2009, p 22), on the other hand, argue that in states with strong institutions it is less likely that natural resources will allow the incumbent government to remain in office.

Collier \& Venables $(2009, \mathrm{p} 8)$ have alluded to the notion that if voters have inaccurate or limited information politicians may be able to embezzle with few consequences. Wantchekon (2000, p 7) also states that when the incumbent has discretionary power over policies of redistribution the government may engage in what is known as a consumption binge, a situation in which taxes are reduced and government spending is geared towards projects that guarantee high immediate visibility.

Wantchekon also shows that the discretion of the incumbent government over how and when to spend revenues enables the incumbent to undermine the credibility of the opposition through a process of upfront payments: the incumbent can spend the money on maintaining and upgrading facilities, promise the voters more and capitalise on its successes. Thus it is possible that the NDC will be entrenched in power for many more years to come.

While oil revenue may provide an incentive to build the capacity of Ghana, to develop infrastructure for economic development and to educate the population, the NDC will have to be cautious. In some cases resource mismanagement can create problems. Incentives to gain access to resource rents may actually weaken a government and make it vulnerable to being overthrown (Collier \& Venables 2009, p 4).

Authors like Kapela (2009, p 12) have warned that when resources are discovered and there are no transparent policies in place to regulate their extraction, corruption permeates throughout government, as a few officials in 
control of the resource rents may be encouraged to consolidate their power by repressing civil society and exercising authoritarianism.

\section{OIL AND THE 2012 PRESIDENTIAL ELECTION: POLITICAL PARTIES, MANIFESTOS AND ELECTION CAMPAIGNS}

The 2012 elections were significant for both parties: the NPP sought to regain power after its defeat in the 2008 run-off election and the NDC had the task of convincing voters that it deserved to continue in office. Political analysts believe the tension that existed during the 2008 elections could be attributed to the high expectations of both parties of the oil revenue from Jubilee. This situation was no different in the 2012 elections and political leaders made promises based on what they could achieve by using oil revenues.

Prior to the 2012 elections the NDC's candidate, John Dramani Mahama, released a manifesto entitled 'Better Ghana', which was interpreted as a continuation or perpetuation of the policies propagated by the late President John Atta Mills (Jahateh 2012, p 1). Mills's death was expected to have a significant impact on the elections: people would vote for Mahama as they believed that the progress made under Mills during his three-year term would continue under Mahama.

Jahateh (2012) writes that Mahama's prospects of victory would be influenced by Ghanaians who would express their condolences and sympathy to the NDC by voting for the party's candidate. It must be noted that Mills lacked the support of the party's founder, Jerry Rawlings, whose influence on the party's grassroots supporters was considerable (Jahateh 2012, p 8). Prior to Mills's death Rawlings had stated that the ruling party would not win another term in power with Mills as leader (Jahateh 2012, p 8).

Internal divisions were not unique to the NDC. Both parties were plagued by internal discord over their candidates. The NDC struggled to distance itself from the influence and legacy of its founder and former president, Jerry Rawlings, (Lowther 2013, p 1) and Nana Akufo Addo of the NPP worked to rebrand his party, which was seen as elitist and pro-upper class.

In the lead-up to the elections the NDC characterised itself as a social democratic party that was in favour of equality for all (Jahateh 2012, p 8). It focused primarily on infrastructural development, a principle contained in the executive summary of the 2012 manifesto, which stated, 'Our infrastructure development will be intensified to accelerate the transformation of Ghana into a middle-income status' (Nonor 2012, p 1).

Thus, in order to attain its goal, in the lead-up to the elections the NDC made various promises pertaining to the use of oil revenues. It stated that it aimed to 
use oil and gas development as a catalyst to diversify its economy and said that if it was re-elected it would strengthen the agencies that controlled the regulation of all segments of the petroleum industry (Top Africa 2012). In its manifesto the NDC also promised to promote local involvement in the exploration, development and production of both oil and gas and provide funding for training and scientific research for the development of the oil and gas sector.

The NDC was able to highlight its achievements within these sectors during Mills's term. It had established the Ghana National Gas Company as a means of guaranteeing the sustainable development of the infrastructure and industry. The debt that had been accrued by the Tema Oil Refinery had been substantially paid off and the refinery was managed sustainably, the manifesto claimed. Thus the NDC was able to use its success and projections for the future to garner support (Top Africa 2012).

The NPP, which was regarded as conservative, in contrast to the NDC, which was seen as socially progressive, promised to 'promote a vibrant free economy'. Both parties promised an equal distribution of oil revenue, the modernisation of agriculture and better education (Lowther 2013). These issues were deemed crucial in the contested race.

The main issues that concerned voters were job creation, corruption and free secondary education (Melimopoulos \& Vetch 2012).

The parties diverged on the issue of free senior high school (SHS) education, which, in the run-up to the elections, was a major issue. While some parties had promised to make basic education compulsory and free, others promised free SHS education. As Nana Akufo-Addo of the NPP put it:

Clearly the most equitable manner in which our nation and our people would benefit from the oil revenue is to ensure that they are used on the two most critical aspects of our national life - our education and our healthcare.

Nonor 2012

While the provision of free secondary education would be costly, it has been acknowledged that Ghana cannot have an uneducated and unskilled workforce. The NPP's manifesto promised free SHS education, which included technical and vocational education. To make this aspiration a reality would require the use of budgetary resources, including those from oil exports.

The NDC countered with the argument that such a promise was neither viable nor sustainable (Nonor 2012, p 1; Commonwealth Observer Group 2012, p 8). Some analysts also argued that Ghana's economy was too small to implement free SHS and the government could not meet such a huge promise while infrastructure 
was inadequate (Kwode 2012). Consequently, the NDC proposed the phasing in of free SHS education over a period of 20 years (Kwode 2012), arguing that building the necessary infrastructure was a prerequisite for attaining such a goal.

Whatever their differences, both parties intended to use wealth accrued from oil and other minerals to prompt industrial growth, improve health services and education and create jobs (Kwode 2012). During a debate organised by the Institute of Economic Affairs Akufo-Addo listed the revenue accrued from oil as a significant source of funding for his free SHS policy. The NPP believed that this would secure him votes among young, urbanised voters (Lowther 2013). The NPP also had the support of the former president, John Agyekum Kufuor. For Afuko-Addo, investing in oil revenue to build Ghana's human resources through education was the answer to developing the state (Nonor 2012).

While the NDC placed more emphasis on infrastructural development, it, like the NPP, believed that it was important to use oil revenues for this purpose.

However, Throup $(2011,5)$ points out that little attention has been paid to the potential impact of mismanagement of resource revenue. Many analysts have argued that Ghana is an 'exceptional state' in Africa and may therefore be able to avoid the resource curse. However, some issues have come under scrutiny.

\section{THE IMPERATIVE TO AVOID THE RESOURCE CURSE}

\section{Transparency and oil resources}

The resource curse within West Africa could provide a cautionary tale for Ghana. Collier \& Venables (2009, p 9) state that without adequate infrastructure and political systems developing states cannot use oil resources successfully because of the greed of political elites and multinational corporations, who may exacerbate unequal distribution of resources. Kapela $(2009$, p 3) notes that Ghana has problems that have the potential to undermine any positive impact of oil and gas development.

Kapela believes the process of oil development is moving too fast because proper institutions have not been put in place to regulate the petroleum industry. Kapela also believes civil society is being marginalised and when it comes to deals between oil companies and regulatory bodies there is a reluctance to be transparent. In order for Ghana to avoid the resource curse, it is argued, there is a need for improved transparency in resource management and monetary and fiscal policies; there have also been proposals to improve government transparency and encourage civil society engagement (Kapela 2009, p 17). It has also been suggested that oil revenues should be used to promote economic diversity and the establishment of an oil fund. 
The Ghanaian government has already passed the Petroleum Commission Act, giving the Ministry of Energy powers to regulate and manage the petroleum sector and issue licences, formerly the responsibility of the Ghana National Petroleum Cooperation (GNPC) (Prempeh \& Kroon 2012, p 10).

The activities of the GNPC had been considered to be opaque and it was believed that it offered employment opportunities to influential NDC representatives, thus its powers have been reduced by the passage of the Petroleum Commission Act. However, the regulatory capacity of the Petroleum Commission are weak and the GNPC poses a problem because its leadership consists of influential members of the NDC and it is considered to be heavily politicised (Throup 2011, p 11).

Kapela (2009, p 20) recommends the creation of a new oil authority which is independent of the GNPC. Prempeh \& Kroon (2012, p 11) argue that transparency in the petroleum sector within Ghana is weak and that although the Petroleum Revenue Management Act (2011) requires the publication of information about petroleum revenue, when it comes to contracts and contracting and licence procedures there is little transparency and budgeting and spending decisions are not explained. For example, the projected budget for 2013 failed to state how much revenue from oil would be allocated to particular sectors or projects (Prempeh \& Kroon 2012).

It is significant that initiatives to establish transparency such as the Petroleum Revenue Management Act and petroleum contracts came from donors and the private sector, not from government (Prempeh \& Kroon 2012, p 11). The Act allows the government to use $70 \%$ of its oil revenues as collateral for loans and to support the budget. The opposition deemed this provision controversial because it believes that if the government is permitted to use oil revenues to raise loans it will give the governing party the opportunity to misuse the revenue (Gary 2012). It may also increase the risk of debt (Throup 2011, p 17). While the Petroleum Act may provide for auditing and transparency what remains to be seen is whether Ghana has the technical capacity to enforce the requirements.

Kapela (2009, p 20) states that many countries do not have the 'autonomous technocracy' necessary to implement unpopular policies pertaining to budgetary spending practices that offset the 'Dutch Disease'. ${ }^{1}$ Botswana is one of the few states to have stipulated that all spending must be approved by Parliament, which ensures that all activities of the executive are checked.

1 'The theory states that windfall profits from commodity exports (eg, natural gas, oil, gold and/or diamonds) will appreciate the exporting nation's exchange rate, making all other export sectors of the economy suffer from less competitive trade terms (ie, non-mineral exports like agriculture and manufacturing become more expensive in international trade)' (Kapela 2009). Also see The Economist, 'The Dutch Disease', 26 November 1977, pp 82-83. 
Contrary to expectations and practice, the control of Ghana's petroleum management and revenue spending lies with an executive agency which is responsible to the president and not to Parliament. All transactions between foreign oil companies and government have been shrouded in secrecy, with information and data classified beyond the reach of civil society. Thus, it is crucial that oil management is overseen by an independent and apolitical institution answerable directly to Parliament (Prempeh \& Kroon 2012, p 27).

Ghana also has low levels of the checks and balances necessary to guarantee executive accountability to other equally important state organs like the judiciary, the legislature and the media (Dessus, Medvedev, Land, Bain, Kwawukume, Andrade, Calvacanti, Stevens, Foster, Vagliasindi, Costain, Jackson \& Byerlee 2009, p 5). Ensuring that oil management is declassified and managed without fear or favour or doom from the executive is critical to avoid the curse embedded in oil discovery. Alternatively, President Mahama's government should, perhaps, look for a means of minimising the risks of creating grievances springing from oil (mis)management. There is a need for consensus among all stakeholders about the management of oil revenues.

Ghana, a major exporter of gold and cocoa, needs to continue to diversify its economy. Hayes has argued that expected oil returns will account for only $6 \%$ of the economy, unlike the situation in Nigeria, where they account for about $92 \%$ (Mitchell 2012). Thus it is in a better position to manage oil resources because it is not entirely dependent on them.

Political grievances can escalate violence in the following way: those who live closest to natural resources may feel they have a greater right to the wealth created by these resources than the rest of the population because they are affected by their extraction (Humphreys 2005, p 31). Thus, distribution of mineral resource wealth should be just and equal, as the NDC believes.

In order to avoid future conflict and tensions among political parties the incumbent party must ensure that the revenues accrued from oil rents benefit all the people of Ghana and that the government does not engage in rent-seeking behaviour. The governing party must seek ways of managing wealth transparently and equitably, as a lack of transparency and accountability may increase political and social tensions in subsequent elections.

\section{CONCLUSION}

Much of the literature on the political economy of oil dwells on the oil-conflict nexus, particularly as it pertains to some of Africa's intractable conflicts such as Sudan and Cold War-era proxy battles like those in Angola. For this reason oil discovery and (mis)management has been construed as a tragedy of sorts. The 
role played by oil in Ghana's 2012 presidential election scarily gave credence to the belief that oil discovery in Africa inevitably leads to an elitist political system which deprives the populace of the improved living standards that should be the result of oil discovery.

This article was premised on the urgency for Ghana to build an apolitical, transparent and accountable institution to manage its oil and report to the people's parliamentary representatives while exerting checks and balances.

The article has attempted to provoke some reflection on the part of the Ghanaian government about engaging in constructive thinking about its oil management policy. Leaving it to the dictates of political parties is a recipe for disaster. The 2012 elections only showed one side of this potential sledgehammer that may disrupt the image of Ghana's political system as a democratic beacon for West Africa and Africa at large.

At this point the extent to which foreign oil companies are involved in the scramble for oil exportation or drilling licences is unclear - but extrapolating from how such foreign interests have sponsored political dissent and proxy wars in the past, it is reasonable to suggest that Ghana's political elite must be watchful about the harm competition among Western, Chinese and other Asian oil companies over its oil could cause to the nation as a whole in years to come.

At best, short term licences should be issued, with an insistence on the employment of Ghanaians, support of indigenous projects as part of corporate social responsibility, public-private partnership with Ghanaians holding top management positions and an emphasis on skills transfer. Such a scheme, which would benefit Ghanaians, will diminish the chances of popular uprisings ensuing from unemployment and will enable Ghana to grow more successfully than Nigeria, Sudan or Angola, which leveraged their oil extraction control to foreign competing forces in the absence of effective government policies and strong institutions.

Beblawi, H. 1987. 'The Rentier State in the Arab World'. In H Beblawi \& G Luciani (eds). The Rentier State. New York: Croom Helm Publishers.

Beblawi, H \& G Luciani (eds). 1987. The Rentier State. New York: Croom Helm Publishers.

Cabrales, A \& E Hauk. 2009. 'The quality of political institutions and the curse of natural resources'. Economic Journal 121(551).

Chaudhry, K A. 1997. The Price of Wealth. Ithaca: Cornell University Press.

Collier, P \& A Hoeffler. 1998. 'On the Economic Causes of Civil War'. Oxford Economic Papers, New Series 50(4). 
Collier, P \& A Hoeffler. 2001. Greed and Grievance in Civil War. Washington: The World Bank.

Collier, P \& A J Venables. 2009. 'Natural resources and state fragility'. OxCarre Research Paper number 31.

Commonwealth Observer Group. 2012. 'Ghana's Presidential and Parliamentary Elections'. London: Commonwealth Secretariat.

Cook, MA (ed). 1970. Studies in Economic History of the Middle East. London: Oxford University Press.

Dessus, S, D Medvedev, B Land, K Bain, S Kwawukume, M Andrade, C Calvacanti, MStevens, V Foster, M Vagliasindi, C Costain, C Jackson \& D Byerlee. 2009. 'Economy-wide impact of oil discovery in Ghana'. Washington, DC: 47321gh, World Bank.

Dunning, T. 2008. Crude Democracy: Natural Resource Wealth and Political Regimes. Cambridge: Cambridge University Press.

Economist, The. 1977. 'The Dutch Disease', 26 November.

Friedman, T. 2006. 'The First Law of Petrol Politics'. Foreign Policy 154.

Gary, I. 2012. 'Elections and Oil - Ghana's Choice'. Oxfam America. Available at: politicsofpoverty.oxfamamerica.org/2012/12/03/ghana-elections-and-oil/ Gorrie, M. 2012. ‘Ghana's 2012 Elections: Thievery or Error?' Foreign Policy Blog, 25 December. Available at: foreignpolicyblogs.com/2012/12/25/ghanas2012-presidential-election-thievery-or-error /

Humphreys, M. 2005. 'Natural Resources and Armed Conflicts: Issues and Options'. In K Bellentine \& H Nitzchke (eds). Profiting from Peace: Managing the Resource Dimensions of Civil War. London: Zed Books.

Jahateh, L. 2012. 'Ghana heads to decisive presidential elections'. Aljazeera. Available at: www.aljazeera.com/indepth/opinion/2012/10/2012101511218436660. html

Kapela, J M. 2009. 'Ghana's New Oil: Cause for Jubilation or Prelude to the Resource Curse'. Unpublished master's thesis, Nicholas School of the Environment, Duke University.

Karl, T. 1997. Paradox of Plenty: Oil Booms and Petrol-State. Berkeley, CA: University of California Press.

Kwode, P A. 2012. 'Can NPP fulfill its free education policy in 2013 when voted into Power?' Ghana News Agency. Available at: www.ghananewsagency. org/ details / Features / Can-NPP-fulfill-its-free-SHS-education-policy-in2013-when-voted-to-power $/$ ?ci=10\&ai $=51402$

LaMonica, C \& J S Omotola (eds). 2013. Horror in Paradise: Frameworks for Understanding the Crises of the Niger Delta Region of Nigeria. Durham, NC: Carolina Academic Press.

Lowther, J. 2013. 'Post-election reflection: Ghana's 2012 presidential and 
parliamentary elections. Consultancy Africa Intelligence. Available at: www. consultancyafrica.com $/$ index.php?option $=$ com_content\&view=article\&id= 1229:post-election-reflection-ghanas-2012-presidential-and-parliamentaryelections-\&catid $=42$ :election-reflection $\&$ Itemid $=270$

Mahdavy, H. 1970. 'The Patterns and Problems of Economic Development in Rentier States: The Case of Iran'. In M A Cook (ed). Studies in Economic History of the Middle East. London: Oxford University Press.

Maplecroft Global Risk Analytics. 2012. 'Election Monitor - Ghana'. Available at: maplecroft.com/portfolio/new-analysis/2012 / 12/12/ disputed-electionghana-may-impact-business-environment-while-zuma-looks-set-secureanc-leadership-s-africa/

Marshall, M G \& J Keith. 2003. Polity IV Project. Centre for International Development and Conflict Management, University of Maryland.

Melimopoulos, E \& C Vetch. 2012. 'Ghana's voices speak out on election issues'. Available at: www.aljazeera.com/indepth/features/2012/12/ 201212713152520185. html

Mitchell, M. 2012. 'Ghana's Offshore Oil: Resource Curse or Blessing?' The Africa Portal. Available at: www.africaportal.org/articles/2012/11/15/ ghana\%E2\% 80\%99s-offshore-oil-resource-curse-or-blessing

Moss, T \& L Young. 2009. 'Saving Ghana from its Oil: The Case for Direct Cash Distribution'. Working Paper 186, Center for Global Development.

Nonor, D. 2012. 'Oil, A silent driver of the 2012 Elections'. The Chronicle. Available at: thechronicle.comgh / oil-a-silent-driver-of-the-2012-elections /

Obi, C. 2007. 'Oil and Development in Africa: Some Lessons from the Oil Factor in Nigeria for the Sudan'. In L Patey (ed). Oil Development in Africa: Lessons for Sudan after the Comprehensive Peace Agreement. Danish Institute for International Studies DIIS REPORT.

Omotola, J S. 2012. 'Election Administration and Democratic Consolidation in Ghana and Nigeria under the Fourth Republic'. Unpublished PhD thesis submitted to the Department of Political Science, University of Ibadan, Nigeria.

Patey, L. 2007. 'Oil Development in Africa: Lessons for Sudan after the Comprehensive Peace Agreement'. Danish Institute for International Studies DIIS REPORT.

Prempeh, H K \& C Kroon. 2012. 'The Political Economy Analysis of the Oil and Gas Sector in Ghana: Summary of Issues for the STAR-Ghana'. STAR, February. Ramsay, K W. 2007. 'Natural Disasters, the Price of Oil, and Democracy'. Mimeo Work in Progress, Department of Politics, Princeton University, September.

Reno, W. 2006. 'Insurgencies in the Shadow of State Collapse'. In P Kaarsholm (ed). Violence, Political Culture and Development in Africa. Oxford: James Currey; 
Athens: Ohio University Press; Pietermaritzburg: University of KwaZuluNatal Press.

Rose, M L. 1999. 'The Political Economy of the Resource Curse'. World Politics 51, January.

Rose, M L. 2001. 'Does Oil Hinder Democracy?', World Politics 53, April.

Ross, M. 2001. 'Extractive Sectors and the Poor'. UCLA, Oxfam America, October. Shaxson, N. 2008. Poisoned Wells: The Dirty Politics of African Oil. Palgrave Macmillan. Throup, D W. 2011. 'A report of the CSIS Africa Program: Ghana: Assessing Risks to Stability'. Washington: Center for Strategic International Studies.

Top Africa. 2012. 'The Ghana Elections NPP \& NDC'. Available at: www.topafric. com/index.php/en/ site-map/306-the-ghana-elections-npp-ndc.html

Tsui, K K. 2005. 'More Oil, Less Democracy?: Theory and Evidence from Crude Oil Discoveries'. Job Market Paper, University of Chicago, November.

Wantchekon, L. 2000. 'Why do Resource-Dependent Countries have Authoritarian Governments?' Working Paper. New Haven: Yale University.

Wantchekon, L\& N Jensen. 2004. 'Resource Wealth and Political Regimes in Africa'. Comparative Political Studies 37(7).

Yates, D A. 1996. The Rentier State in Africa: Oil Rent Dependency and Neocolonialism in Gabon. Trenton, N J: Africa World Press. 